\title{
TRATAMENTO DA MÁ-OCLUSÃO DE CLASSE III COM DISJUNÇÃO PALATINA ASSOCIADA À TRAÇÃO REVERSA DA MAXILA
}

Viviane KAGY, Alexandre MORO

A expansão maxilar e a terapia com máscara facial na má-oclusão de classe III proveniente de uma deficiência maxilar, têm sido utilizadas com muito sucesso na fase de dentadura decídua e mista. A disjunção da maxila é realizada em conjunto, tendo por finalidade, romper o sistema de suturas faciais, facilitando o movimento anterior da maxila. Além da máscara facial, a tração reversa da maxila também pode ser realizada por meio de uma mentoneira de ação reversa (Sky Hook) que traciona a maxila para anterior através de elásticos. O objetivo deste trabalho é relatar um caso clínico onde foi realizado o tratamento da má-oclusão de classe III, na fase de dentadura mista devido a uma deficiência de crescimento antero-posterior da maxila. A paciente de 6 anos apresentava mordida cruzada anterior e posterior, padrão braquifacial, retrusão maxilar e protrusão da mandíbula. O tratamento foi realizado com expansão rápida da maxila, utilizando um disjuntor de Haas com ativação de um quarto de volta por dia, durante quinze dias, associado à tração reversa da maxila, por meio de uma máscara facial com $500 \mathrm{~g}$ de cada lado por aproximadamente 12 meses. Os traçados cefalométricos inicial e póstratamento confirmam o bom resultado promovido pelo tratamento.

Palavras-chave: Maloclusão; Má Oclusão de Angle Classe III ; Aparelhos de Tração Extrabucal. 